\title{
Feeding Mara: An Examination of Redemption in the Book of Ruth
}

\author{
Chesirae Valentine \\ Boston College School of Theology and Ministry (Brighton, MA)
}

\begin{abstract}
Traditionally understood as an exercise in feminist theology or political storytelling, the Book of Ruth's ministerial potential remains untapped. Ruth acts as more than a feminist icon or political example when she redeems Mara — she acts as the hands of God. Though often read through a historical or feminist lens, I propose that the Book of Ruth is primarily a liberation text, answering Ignacio Ellacuría's question: "What must I do to uncrucify [the suffering]?" When Naomi becomes Mara, she becomes representative of every person who has suffered under systemic oppression. Ruth, by meeting Naomi in her pain and answering it, becomes representative of God. The path to Naomi's redemption then becomes the path the Church might tread to serve, liberate, and comfort those who are systematically oppressed.

Ruth ultimately redeems Naomi through three actions. First, by pledging solidarity of experience with Naomi, Ruth promises to trust Naomi / Mara's experiences as valid and worthy, and does not presume to narrate Mara's suffering. Second, by listening to and providing for Mara's needs, Ruth does not presume to pity, but rather to understand and liberate Mara's immediate suffering. Third, by trusting Mara's needs and experiences, Ruth can comfort Naomi through creating a new system: a new family through Obed. By creating a new space where Mara is freed from her bitterness, Naomi can exist once again.

The Book of Ruth becomes a parable that explores the way God's compassion may work in and through human systems to redeem the oppressed. This article explores that parable, and begins to answer how the Church — as God's earthly hands — might begin to do this work for systematically oppressed people.
\end{abstract}

\section{Text}

The Book of Ruth is about starvation, about food, about neglect and nourishment. Ten years before the events of Ruth take place, Elimelech and his wife Naomi flee from Bethlehem to Moab, seeking relief from famine. It is in Moab that their son Chilion marries Orpah, and Mahlon marries Ruth — the family, after fleeing starvation, has been satisfied in the land of Moab. But Elimelech, Chilion and 
Mahlon die of illness, leaving their widows on the edge of starvation once again. Without their men, these widows are left without land or income, with no recourse to a levirate marriage (Lv. 25:25). ${ }^{1}$ The levirate law as laid out in Leviticus, intended to care for the community by maintaining family lineages, has actually created a system that will destroy its members - Naomi is physically incapable of bearing another son to carry Elimelech's name (Ru. 1:11-13), and Ruth, as a Moabite, is not allowed. ${ }^{2}$ It is at this point that the Book of Ruth becomes more than a historical example of conversion, a political analysis of the time of Judges, or a feminist text. It speaks of ministerial care without obvious salvific miracles - Ruth and Naomi's hunger will not be fed by manna or resolved by God's voice, but rather through Ruth's creative labors. Ruth should be read as God's manifestation in our daily, adult work. In the Book of Ruth, God is not a powerful parental figure, alternately loving and judging the Israelites, and stepping in when they despair. Instead, God's presence is manifested through the conscientious effort of Ruth, the Moabite outsider. It is Ruth who chooses to remain faithful to God's command to "rescue the oppressed, defend the orphan, plead for the widow" (Is. 1:16-17). Even unqualified, even as an outsider, it is Ruth that pledges solidarity with Naomi, and Ruth who ensures Naomi's redemption. The Book of Ruth can thus be read as a parable — Ruth represents God's own fidelity and creativity in comforting individuals facing extreme suffering and oppression.

As seen in Ruth, God acts in three ways to redeem those in systems of oppression. First, through Ruth's solidarity vow with Naomi, God pledges to remain loyal and empathetic to the experience of those who suffer, as well as refusing to abandon those who reject God. Secondly, God desires alleviation for those who suffer in material ways - Ruth's creative approach to the gleaning law sustains Naomi through the season. Finally, when Ruth listens to and enacts Naomi's plan for their redemption in society, she does not redeem Naomi to the same society that has oppressed her, but to a new and different society, one created with the birth of Obed. Similarly, God does not redeem in the same system that is broken, but rather through a new system that is created.

Ruth's vow of solidarity with Naomi comes immediately after she has been rejected. Though Naomi, Orpah and Ruth have all left Moab together for Bethlehem, all three seeking food and sustenance together, Naomi demands that they "Go [and] return each of [them] to [their] mother's house." Orpah, after refusing once,

\footnotetext{
${ }^{1}$ All quotations are taken from the NRSV.

2 The levirate law is the custom of a close kinsman marrying his brother's widow, in order to keep his brother's name alive. This law is famously carried out in Genesis 38, where Tamar is the unfortunate widow of two brothers. This law, however, was only for the people of Israel, in order to preserve and care for the limited bloodlines, and it was only a provision for brothers of the deceased husband. For more about the effect of levirate laws on the Hebrew culture, see the Mishneh Torah by Maimonides.
} 
weeps as she turns to go back into Moab. But Ruth stubbornly stays, declaring that she will experience all aspects of life with Naomi, that "Where [she] goes, [Ruth] will go; where [she] lodges [Ruth] will lodge; [her] people shall be [Ruth's] people, and [Naomi's] God, [her] God" (Ru. 1:16-18). Even though Naomi has rejected Ruth, pushed her away, demanded that she leave her for a new life, Ruth remains loyal. "So the two of them went on to Bethlehem" (Ru. 1:19), where Naomi is recognized by her former friends and neighbors, but Naomi rejects their recognition. She is no longer Naomi; instead she asks that they "call her Mara" for she "went away full, and the Lord brought [her] back empty" (Ru. 1:20-21). Naomi's entire identity has altered because of her experience of hardship. She is no longer full of joy, but rather bitter and wasted. Ruth, while she has promised to follow Naomi, share her life, and undergo the same experiences, does not undergo the same identity transformation. Ruth remains herself, even while empathizing with Mara.

By remaining independent of Mara's identity change, Ruth retains the ability to act without the debilitating bitterness and depression that marks Mara's life. This ability is necessary for the Church and the pastoral caregiver to keep in mind. For the pastoral caregiver who pledges poverty with the congregation, or the Church that remains fidelius through civil war, the ability to remain hopeful and unaltered by sorrow or bitterness is crucial for creative and healing action. As Carrie Doehring points out in her text on pastoral counseling, if Ruth were to over identify with Mara, it would, "make it difficult for [her] to be aware of her own feelings and at the same time monitor what is happening in the relationship." 3 If the caregiver or Church overly sympathizes with their congregation or careseekers, the gift of charity and just action will be twisted by personal rage and resentment. Ruth, though she experiences the same injustice and misfortune that Mara does, refuses to allow those experiences to dictate her faith or identity.

Ruth's independence allows her to care for Mara, to "go to the field and glean among the ears of grain" (Ru. 2:2). Mara allows this with a curt, "Go, my daughter", and remains in her bitter state while Ruth seeks a field to glean from. Under Judaic law, Ruth should not be able to do this - Ruth is a Moabite, she is a foreigner to whom the law does not apply (Lv. 19:9-10). But, in order to sustain Mara, she must find a way to feed her. So Ruth begins to glean in a field owned by Boaz, a close kinsman of Elimelech. While asking permission to glean his fields, Ruth reveals her knowledge that the law does not necessarily apply her, and gently asks that generosity be extended regardless ( $\mathrm{Ru}$. 2:7). It is this resolution to nourish Mara that makes Ruth bold, and that boldness which encourages Boaz to bend the traditional law to include the neglected women and save them from starvation. Ruth asks Boaz, "Why have I found favor in your eyes, that you should take notice of

\footnotetext{
${ }^{3}$ Carrie Doehring, The Practice of Pastoral Care: A Postmodern Approach, (Westminster: John Knox Press, 2006), 19.
} 
me, when I am a foreigner?” (Ru. 2:11). Boaz responds that her loyalty to Mara, even in her own pain and suffering, has moved him. Here, it is Ruth's practical care for Mara's hunger that bends the oppressive system, rather than any concern over Mara's spiritual state.

Gleaning in the fields does not redeem Naomi and Ruth within the oppressive system that has condemned them, but — through Boaz's sympathy — it has created a tangible reprieve that will alleviate the immediate effects of oppression. For the Church or pastoral caregiver, this example can immediately be applied. The reprieve from hunger, pain, cold and humiliation are not only charitable acts, but crucial for the spiritual well-being of anyone under oppression. Like Ruth, the Church or caregiver must be able to provide sustaining resources for the careseeker. This provision includes both intangible advocacy in the face of the law (as Ruth humbly advocates for Mara in the fields), as well as basic needs like nourishment, shelter and protection. These provisions alleviate the suffering of individuals or communities, allowing them to look forward to a space where they will longer struggle to survive under oppression, but liberate themselves from it.

Alleviation of the symptoms of oppression has too often been considered satisfactory for spiritual care, not only by the ancient Hebrew communities, but in our modern systems as well. For example, rather than criticize or reform economic structures that create millions of impoverished individuals, the called for solution is to "eradicate poverty" through church-run food banks, shelters and direct donations. But alleviation is not redemption. At best, alleviation entrenches the effects of oppression, allowing a select few communities moments of reprieve that are entirely dependent on their benefactors, while allowing the unoppressed the satisfaction of accomplishment.

In other words, what would have become of Mara, had Boaz changed his mind?

In the Book of Ruth, that is not a realized concern, because Boaz remains beneficent through the harvest. This allows Mara a break from her bitterness though she has lost everything, her physical needs are taken care of long enough for her to recall what an unoppressed life would be. Throughout Chapter 2, Ruth made a point of prioritizing Mara's advice over Boaz's (Ru. 2:21-23), ${ }^{4}$ elevating Mara's needs and concerns over the concerns of their benefactor. When Chapter 3 begins, Ruth is still in a posture of listening, as she agrees to Mara's plan to "seek a home for [her], that it may be well with [her]" (Ru. 3:1). Mara's plan for redemption requires that Ruth prepare herself as a bride, hide herself on the threshing floor,

${ }^{4}$ Ruth misquotes Boaz, claiming that he said she should stay with his (male) servants in the field. But Boaz actually told Ruth to "stay close to [his] maidens" (Ru. 2:8). So though Boaz and Naomi have not yet met, they're surprisingly synchronized on how Ruth should attend to her gleaning activities. 
and lie with Boaz ${ }^{5}$. This is no mere bending of Judaic law — this is scandal. But Ruth's trust in Mara's plan is not foolish. She has heard what Mara needs and listens to her - Boaz's generosity cannot be endlessly relied on, unless he sees them as family. It is crucial to notice, however, that Mara cannot foresee what actually allows the plan to succeed. Mara told Ruth that, after presenting herself, she needed to listen to Boaz, for "he would tell [her] what to do." (Ru. 3:4) But what sways Boaz to advocate for Ruth as a wife is her entreat that Boaz, "spread [his] wings over his maidservant" (Ru. 3:9) ${ }^{6}$ - a blessing that Boaz prayed over Ruth in chapter 2, and a interchange that Mara has no knowledge of. It is not Boaz telling Ruth what to do, it is Ruth telling Boaz.

It is Ruth's creative and practical interpretation of Boaz's prayer that "a full reward be given [to her] by the Lord...under whose wings [she has] come to take refuge" that encourages Boaz to further bend the system in place ( $R u$. 2:13). Though there is a closer kinsman-redeemer introduced in Chapter 4, Boaz makes it clear to the kinsman that the land previously owned by Elimelech cannot be redeemed without Ruth. This is a departure from the common interpretation of levirate law, where Mara would be redeemed along with the land, but Ruth the Moabite excluded. With this subtle shift, Boaz ensures his union with Ruth and brings about a fuller redemption of Mara - one that goes beyond land and personal sustenance and extends to children and family lineage. Mara, too old to bear children, could never create a new family for herself. But Ruth can.

At the end of the Book of Ruth, with the birth of Obed, Ruth has created a new family for Mara that comforts, feeds, and sustains her. The same women who recognize Naomi in the first chapter praise the birth of Obed as the one who will be for Mara a "restorer of life and nourisher of [her] old age" (Ru. 4:15). It is obvious that, though Mara's hunger was alleviated by Boaz, she was fed and nourished by Ruth. Obed's birth fully integrates Naomi back into the community, rejuvenating her joy and creating a new social system through the levirate family. The old system - one in which Mara would have married the kinsman redeemer and Ruth would have been cast aside - was not a solution to Mara's oppression. A new system, brought about by Ruth's ingenuity and creativity, was necessary for Mara to be reconciled to Naomi, and the widow to be reconciled to the city.

There are known systems of oppression that pastoral caregivers and the Church thoughtlessly participate in, such as certain exploitative aspects of global capitalism, as well as institutional hierarchies established on heterosexuality or race. As theologians and ministers, work within these systems is encouraged. We

${ }^{5}$ There are many interpretations of what Mara actually intends by sending Ruth to Boaz. The interpretations range between deliberate seduction to a dramatically visual presentation dependency.

\footnotetext{
6 The words "wings" and "skirt" are the same in Hebrew.
} 
are put in the place of Boaz — the one with strong faith, respect for the law, and the grace and freedom to bend the law for those oppressed by it. But my suggestion is that we become Ruth. We act around the established system to create something new and wholesome. We do more that empathize with or alleviate the suffering of the oppressed, we comfort the afflicted the way God comforts - through creative redemption.

\section{Bibliography}

Doehring, Carrie. The Practice of Pastoral Care: A Postmodern Approach. Westminster: John Knox Press, 2006. 